\title{
Editorial: Frontiers in Southeast Asian Geosciences
}

\author{
Basilios Tsikouras $^{1 *}$, Satria Bijaksana ${ }^{2}$ and Yudi Rosandi ${ }^{3}$ \\ ${ }^{1}$ Faculty of Science, Geosciences Programme, Universiti Brunei Darussalam, Bandar Seri Begawan, Brunei, ${ }^{2}$ Faculty of Mining \\ and Petroleum Engineering, Institut Teknologi Bandung, Bandung, Indonesia, ${ }^{3}$ Department of Geophysics, Universitas \\ Padjadjaran, Sumedang, Indonesia
}

Keywords: Southeast Asia, tectonomagmatic, geophysics, natural hazards, environmental geology, exploration

Editorial on the Research Topic

Frontiers in Southeast Asian Geosciences

\section{INTRODUCTION}

Southeast Asia is situated at the junction of four major tectonic plates (Eurasian, Indian-Australian, Pacific, and Philippine Sea) and a few smaller microplates, hence it is one of the regions with the most complicated geological histories on our planet. It is an area which includes a broad spectrum of fascinating geological formations and structures, spanning from the Precambrian till today, active tectonics with some of the highest mountains of Earth, volcanic activity, and an immense supply and deposition of sediments into its basins. The region of Southeast Asia has attracted the attention of researchers with diverse expertise and the amount of research outputs shows an increasing trend in the last few years, as in the past geological research was unfavorable, due to the occurrence of extensive rainforests and unexplored areas and hence limited accessibility. This geoscientific diversity hosts some of the most important economic deposits and formations on Earth thus making the study of Southeast Asian geology even more attractive and imperative.

This Research Topic presents a collection of 16 papers related to the 2nd International Congress on Earth Sciences in SE Asia (ICES 2019), which was held in Bali, Indonesia on 18-20 November 2019. The congress fostered communication and exchange of ideas among young and senior geoscientists from a diverse spectrum of scientific disciplines and facilitated a constructive scientific dialogue.

\section{TECTONOMAGMATIC EVENTS}

Breitfeld et al. study the tectonomagmatic evolution of the Schwaner Mountains (SW Borneo Island) providing new zircon $\mathrm{U}-\mathrm{Pb}$ and ${ }^{40} \mathrm{Ar} /{ }^{39} \mathrm{Ar}$ age dates, which contradict previous dates and hypotheses. The authors reveal the complex geotectonic history of the area, which involved a Paleo-Pacific subduction in Triassic-Jurassic followed by Jurassic rifting and separation of NW Australia from SW Borneo. A subsequent post-collisional Cretaceous magmatic episode followed the collision of Argo and Banda Blocks with Sundaland. A series of Cretaceous meta-volcaniclastic rocks is metamorphosed during the intrusion of the Cretaceous granitoid rocks. 
Burrett et al. report thorough petrological studies, generating a preliminary tectonic model, which describes the geological history of Southeast Asian terranes. The authors present the analysis of integrated data to reveal chronological processes that built up Indochina Terranes.

Hunyek et al. have studied the intrusion of calc-alkaline acidic to intermediate dykes into a Late Permian granite in the Nakhon Ratchasima Province, Thailand. The authors have calculated the P-T conditions of their crystallization to range between 4.5 and $5.5 \mathrm{Kbar}$ and $861-927^{\circ} \mathrm{C}$. These intrusions are related to the Late Permian subduction of the Paleotethys beneath the Indochina Terrane.

Jitmahantakul et al. applied structural restoration techniques in Wichianburi Sub-basin of the Phetchabun Basin in central Thailand and revealed that most of the deformation was concentrated during the Late Oligocene. The restorations show that the extensions of the Wichianburi sub-basin decrease from $12.30 \%$ during the main rift phase (Late Oligocene to Early Miocene) to $2.53 \%$ during the second phase of rifting.

Ndari et al. presented an auxiliary parameter, i.e., preferred pore orientation, to complement the anisotropy of magnetic susceptibility (AMS) technique to decipher lava flows from Batur Volcano in Bali, Indonesia. This method is important especially in Southeast Asia, which itself is a part of Pacific Ring of Fire and a home of scores of volcanoes.

\section{ENVIRONMENTAL APPROACHES}

Chawchai et al. analyzed direct and indirect land-use changes and report a considerable increase of oil palm plantations mainly replacing an evergreen forest, wetlands, and peatlands in the Princess Sirindhorn Wildlife Sanctuary, Narathiwat, Thailand. The study was conducted in two spans (2000-2009 and 20092016) and the authors have calculated the adverse effect on the carbon storage budget reporting a change of $4 \times 10^{6} \mathrm{Mg} \mathrm{C}$ in the 16 years of the study.

Nurshal et al. present an evaluation of digital surface models (DSM) techniques for the identification of fractures in rocks in inaccessible areas and when a typical scanline is not possible. The authors conclude that DSM combined with RGB filtering process provides the optimum and most realistic results.

\section{GEOPHYSICAL CONTRIBUTIONS}

Harsuko et al. improved the method to interpret the horizontalto-vertical spectral ratio (HVSR) of microtremor data using the Hilbert-Huang Transform algorithm. The method was applied to the survey data performed in Lombok Island, Indonesia. The authors report the robustness of the method in order to remove transient monochromatic noise.
Hidayat et al. applied the passive seismic tomography (PST) method to delineate $3 \mathrm{D}$ regional seismic velocity structure in the Banyumas Basin in Central Java, Indonesia. The authors used 70 seismograph borehole stations in the vicinity of the basin. In the region of Southeast Asia there are numerous sedimentary basins, which contain volcanic deposits thus hindering subsurface mapping using conventional 2D seismic reflection methods, which have been attempted, so far. This paper provides innovative $3 \mathrm{D}$ seismic data and a methodology in a contribution to overcome this obstacle.

Jamaludin et al. conducted seismic studies in a sequence of limestones in the Luconia shelf and determined the complex multi-stage tectonic history of the region. They report three mainly compressional events, which occurred from Upper Eocene till Upper Miocene, and are associated to the closure of the Proto-South China Sea and the evolution of the South China Sea, at the southern parts of Luconia. These major tectonic events have largely influenced the Luconia platform and created a hyper-stretched crust at its northern parts resulting in a significant rise of the mantle in that area.

Phujareanchaiwon et al. used outcrop gamma-ray log spectrometry to reconstruct the depositional environment and petroleum source rocks of the Huai Hin Lat Formation in central Thailand. A combination of the $U$ spectral gamma and the conventional gamma ray log has been shown to be effective in identifying organic-rich rocks.

Priyanto et al. used bathymetry and sparker seismic methods, as well as satellite imaging to measure the flank failure and collapse of Anak Krakatau. The methods have successfully predicted the volume of the collapsing materials, which could be a trigger for other natural events, such as tsunamis.

Priyono et al. presented the earthquake aftershock processing methods in order to calculate the attenuation structure of its seismic waves. The authors showed the tomography calculated from an event that took place at Lombok, Indonesia, in 2018.

Sarjan et al. utilized the ambient seismic noise tomography to determine the shear velocity map of Lombok Island. The authors applied the fast-matching surface tomography (FMST) to obtain a tomographic image of group velocity. The method has successfully delineated the upper crustal structure of the Island.

\section{GEOHAZARDS}

Kongsen et al. distinguished Late Holocene storm deposits from shore-normal beach sediments from the Gulf of Thailand using grain-size analyses coupled with detailed description of the sedimentary structures and luminescence dating. This finding is important in studying the frequency and intensity of storm in ancient time.

Kusumawati et al. analyzed the $2016 \mathrm{Mw} 6.5$ Pidie Jaya earthquake, and its aftershock distribution using the fault 
instability criterion and integrated it with the static Coulomb stress change. The static Coulomb stress change is not always positive in all the aftershocks, but the instability value is always high.

\section{AUTHOR CONTRIBUTIONS}

All authors wrote the editorial, have made a substantial, direct, and intellectual contribution to the present work, and approved it for publication.

\section{ACKNOWLEDGMENTS}

ICES 2019 was organized collaboratively by Universitas Padjadjaran and Universiti Brunei Darussalam. The authors gratefully acknowledge the contribution of Professor Robert Hall to the preparation of this special issue and his endless support throughout all stages of this Research Topic. We are grateful to all authors, reviewers, and editors, as well as the ICES 2019 organizers and participants that have contributed to development of this Research Topic.

Conflict of Interest: The authors declare that the research was conducted in the absence of any commercial or financial relationships that could be construed as a potential conflict of interest.

Publisher's Note: All claims expressed in this article are solely those of the authors and do not necessarily represent those of their affiliated organizations, or those of the publisher, the editors and the reviewers. Any product that may be evaluated in this article, or claim that may be made by its manufacturer, is not guaranteed or endorsed by the publisher.

Copyright (C) 2021 Tsikouras, Bijaksana and Rosandi. This is an open-access article distributed under the terms of the Creative Commons Attribution License (CC BY). The use, distribution or reproduction in other forums is permitted, provided the original author(s) and the copyright owner(s) are credited and that the original publication in this journal is cited, in accordance with accepted academic practice. No use, distribution or reproduction is permitted which does not comply with these terms. 